\title{
Selected spatial effects of the global financial and economic crisis in Ljubljana, Slovenia
}

In 2007, the United States witnessed a financial crisis that gradually developed into one of the most serious global financial and economic recessions in the history of (post)modern society. Its effects are numerous. This article studies one of its spatial effects; that is, newly built (after 2005) residential and office buildings that are either unfinished or already built but not fully occupied. In Ljubljana in November 2011, there were ninety-seven locations with unoccupied or partly occupied residential houses and office buildings or groups of houses and office buildings together with abandoned or active construction sites. The majority of the structures studied were predominately represented by several blocks of flats and groups of dwellings. The others are office buildings or buildings and complexes with distinctively mixed residential-business functions. There are more than 1,500 empty flats and almost $75,000 \mathrm{~m}^{2}$ of office area in the buildings surveyed. Spatial analysis showed that the structures surveyed are relatively scattered throughout Ljubljana. However, there were some clusters of buildings, especially in areas with the best accessibility. This article analyses the causes of this phenomenon, which is creating a new morphological element in Ljubljana. The article concludes by stating possible directions for future research.

Key words: economic geography, urban geography, financial and economic crisis, spatial effects, real estate, Ljubljana, Slovenia 


\section{Introduction}

In 2007, the United States witnessed a financial crisis that gradually developed into one of the most serious global financial and economic recessions in the history of (post) modern society (International Monetary Fund, 2008; European Commission, 2009; Deep Sharma \& Mahendru, 2011). The consequences of the financial and economic crisis, which expanded to include almost all economically developed countries in 2008, including Slovenia, are reflected in a decrease in economic activity (manufacturing and trade), higher unemployment, a decrease in the welfare of the population, a loss of confidence in the financial markets, a sharp decrease in stock indexes and real estate values, the bankruptcy of some banks, the emergence of the debt crisis in Europe and changed relations in economic power between developed and developing countries (Adair et al., 2009; Jagannathan et al., in press).

When studying the causes and effects of the financial crisis and economic recession, the main research topics were macroeconomic factors such as the crisis in the banking sector, negative effects of financial globalisation and the lack of supervision over the functioning of banks (see Greenspan \& Kennedy, 2008; Hodgson, 2009; Lawson, 2009; Stiglitz, 2009; Deep Sharma \& Mahendru, 2011; Jagannathan et al., in press). Researchers paid special attention to difficulties that emerged on the real estate market, above all to the housing bubble bursting. Many researchers have analysed the causes and effects of the housing bubble and the situation after it burst in individual countries (e.g., Holloway, 2008; Adair et al., 2009; Diewert et al., 2009; Parkinson et al., 2009; Kitchin et al., 2010; Priemus, 2010; Yao et al., 2010; Jagannathan et al., in press). The latest condition of the Slovenian housing market is presented in the annual report published by the Surveying and Mapping Authority of the Republic of Slovenia, but research publications on the topic are scant. In any case, there have been some research articles analysing the recent development of the Slovenian housing market, mostly written by Richard Sendi (see, e.g., Sendi, 2010). The majority of authors have mainly focused on economic perspectives and effects of the financial and economic crisis, including the situation on the housing market. Detailed geographical analyses are less common. Geographical aspects of the financial crisis have been studied by many researchers (e.g., Aalbers, 2009; Bieri, 2009; Engleman \& Faulconbridge, 2009; French et al., 2009; O’Brien \& Keith, 2009; Wojcik, 2009), but Ron Martin (2011) stated that there has been a lack of regional analyses that sought to answer the two most important geographical questions: first, which geographical factors influenced the beginning and the development of the financial crisis and, second, what the spatial differences are in types and intensity of the consequences of the financial and economic crisis at the global and local spatial levels. To this finding it is necessary to add the lack of micro-location studies that analyse concrete geographical (spatial) consequences of the crisis. This article contributes to this topic by studying unoccupied newly built dwellings in Ljubljana, Slovenia. A number of unoccupied real estate projects and abandoned construction sites could be seen in Ljubljana after 2009. There are new blocks of flats and office buildings that have remained unoccupied for a long time. Therefore, the intention was to survey and analyse the location characteristics of these new elements in the morphological structure of Ljubljana. These are seen as a direct spatial consequence of the (global) financial and economic crisis.

The aim of this study, which was conducted at the end of 2011, was to create an inventory and analyse the location characteristics of the following types of real estate:

- Unoccupied or partly occupied residential houses and groups of houses built for the market after 2005;

- Unoccupied or partly occupied office buildings and groups of buildings built for the market after 2005;

- Active construction sites;

- Abandoned construction sites.

The goals of the study were:

- To survey the real estate that meets the selection criteria mentioned above;

- To prepare an inventory of the real estate surveyed;

- To carry out a location analysis of this real estate.

Three hypotheses were prepared:

1. The global financial and economic crisis caused the crisis on the real estate market in Ljubljana;

2. There are more than fifty locations with recently built flats or office buildings that are still partly or fully unoccupied;

3. The real estate surveyed is mainly located in areas easily accessible by car.

After defining the methods used, the results of the inventory and location analysis are presented. Finally, the reasons are described for the existence of the structures examined in the discussion.

\section{Methods}

\subsection{Field inventory}

A field inventory was used to survey all built but empty or partly occupied residential and office buildings that were built for the market after 2005: blocks of single-family houses, semi-attached houses, detached houses, flats and office buildings. House-extensions, reconstructions, public buildings, single-family houses built by individual investors for their own 
residential use, flats built by public housing funds (national or city) and shopping malls were not on the list of structures studied. Furthermore, a list was prepared of active or abandoned construction sites developed after 2005. This timeframe was selected to correspond with the beginning of the housing bubble in Ljubljana. Buying real estate during the financial and economic bubble until the end of 2008 was often seen as an investment opportunity because its value increased by more than $10 \%$ annually. The demand led to increased construction of flats and office buildings. Due to the financial and economic crisis, after 2008 much new real estate remained unoccupied.

A field inventory was conducted at the end of November 2011. At that time, construction was still possible while the weather conditions for operations were favourable. During the field inventory, the following were of interest: the name of the building/complex, the address, the category (predominantly residential building, predominantly office building, distinctively mixed functions), the investor, the building contractor, the year construction began, the year of construction, the state of the project (finished/unfinished; active/abandoned construction site) together with the number and area of the residential or office buildings. A field certificate was prepared for each piece of real estate, and its location was marked on a 1:20,000 topographic map. The individual research unit was either an individual residential or office building or a group of buildings composed of a number of buildings (e.g., a block of single-family houses or an office complex). Field research was carried out by two groups of researchers. Each group surveyed the entire territory of Ljubljana (on foot, by bicycle or by car). For every appropriate piece of real estate, a form was completed and the location of the real estate was marked on the map. Two field surveys were carried out in order to optimise and obtain more precise information on the structures studied. At the end of the survey, the findings of both groups of researchers were compared. If the data between these two groups differed for an individual site, the results of the pilot field survey prepared in April 2011 were also used and the problematic real estate was visited.

\subsection{Creation of the register}

Missing data were gathered about the number of flats, area of real estate, and share of unsold or unoccupied flats/houses or unoccupied office floors with information from the web portals of real estate agencies, the web pages of individual projects and the web portal of the Surveying and Mapping Authority of the Republic of Slovenia. Based on the method used for capturing field data and the subsequent analysis of web pages, it is estimated that the data gathered were $85 \%$ correct. The greatest difficulties were estimating the share of unoccupied dwellings because it was difficult to make a precise estimate of unoccupied area from the data on the overall area of dwellings and from the field survey data. The share of unoccupied area was usually calculated from the number of unoccupied flats, but this information is partly incorrect because flats vary in their area. To overcome this methodological difficulty, data on unoccupied area were recoded into three groups: predominantly unoccupied dwellings (share of unoccupied area between $100 \%$ and $75 \%$ ), partly unoccupied dwellings (share of unoccupied area between $74 \%$ and $26 \%$ ), and mostly occupied dwellings (share of unoccupied area below 26\%). The register (an Excel file) also included data about the location of the surveyed real estate in the individual district of Ljubljana. Each research unit was defined by a unique number (identification) that made it possible to link the register with spatial data. The locations of the dwellings were digitised. A set of spatial data was created that enabled spatial analysis using the ArcView (ArcMap) software package.

\subsection{Statistical and spatial analysis}

Dwellings included in the register of unoccupied or partly occupied residential and office buildings were analysed using descriptive statistical methods and calculation of relative numbers. Distances of dwellings from the most important roads (state roads and main city roads) were calculated and defined if dwellings clustered together or showed a random pattern by calculating the nearest neighbour index, all by using the ArcView software package. Distances from main roads were calculated according to centroids of buildings or groups of buildings. Therefore, buildings near important roads are, mathematically speaking, up to a few dozen meters away from roads. The recoded data were analysed. The nearest neighbour index is a ratio of the average distance between the closest dwellings and average distance if the structures were randomly distributed (Hammond \& McCullagh, 1974). Values less than 1 show a clustering trend. In this example, that would mean that the dwellings studied are located only in some parts

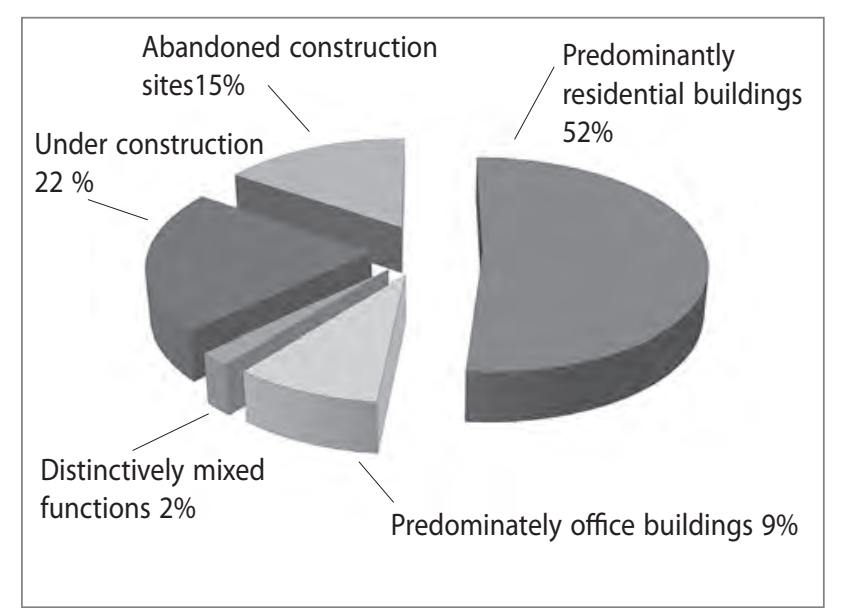

Figure 1: Structure of dwellings surveyed in Ljubljana. 
of the city. Index values above 1 (the highest value is 2.15 ) show dispersion, or random distribution (Geoib, 2012).

\section{Results}

Altogether ninety-seven locations were recorded for unoccupied or partly occupied residential and office buildings built after 2005 and active or abandoned construction sites in Ljubljana at the end of November 2011. The majority, or $78.3 \%$, of the locations surveyed were represented by residential buildings or groups of buildings (seventy-six locations). The survey included fifteen predominantly office-building locations $(15.5 \%)$ and six locations with buildings or complexes with distinctively mixed functions (6.2\%).

Predominantly residential buildings were represented by various types of dwellings: from semi-attached houses, individual multi-dwelling houses or detached houses to groups of individual houses, semi-attached houses or blocks of flats. Residential buildings were distributed relatively evenly around Ljubljana, but there were some areas showing clustering. The trend towards clustering was also proved by the nearest neighbour index with a statistically significant value of $I=0.8117(p=$ 0.00). Important clusters were found along Dunajska Cesta, especially at Dunajska Cesta and the northern ring road junction, around the medical centre, between Vrhovci and Rožna Dolina and in the Jurčkova Cesta area. In Moste, Štepanjsko Naselje, Studenec, BTC, Trnovo, Sibirija and Rakova Jelša no dwellings were discovered that would have been suitable for this research.

Clustering of the dwellings studied was also confirmed by the analysis at the city district level. The greatest number of dwellings studied were surveyed in the Rudnik and Rožnik districts, with more than ten residential locations in each. In the Šška district, nine residential locations were found, and in Bežigrad and Center there were eight locations. The lowest number of eligible locations was found in the districts of Šmarna Gora (one location), Dravlje (two locations), Črnuče and Jarše (in both districts there were three locations of residential buildings). In other districts no residential dwellings were found that would be eligible for this study. Predominantly residential real estate was located 250 to $500 \mathrm{~m}$ from main roads in Ljubljana (twenty-three locations, or 30.3\%). Around

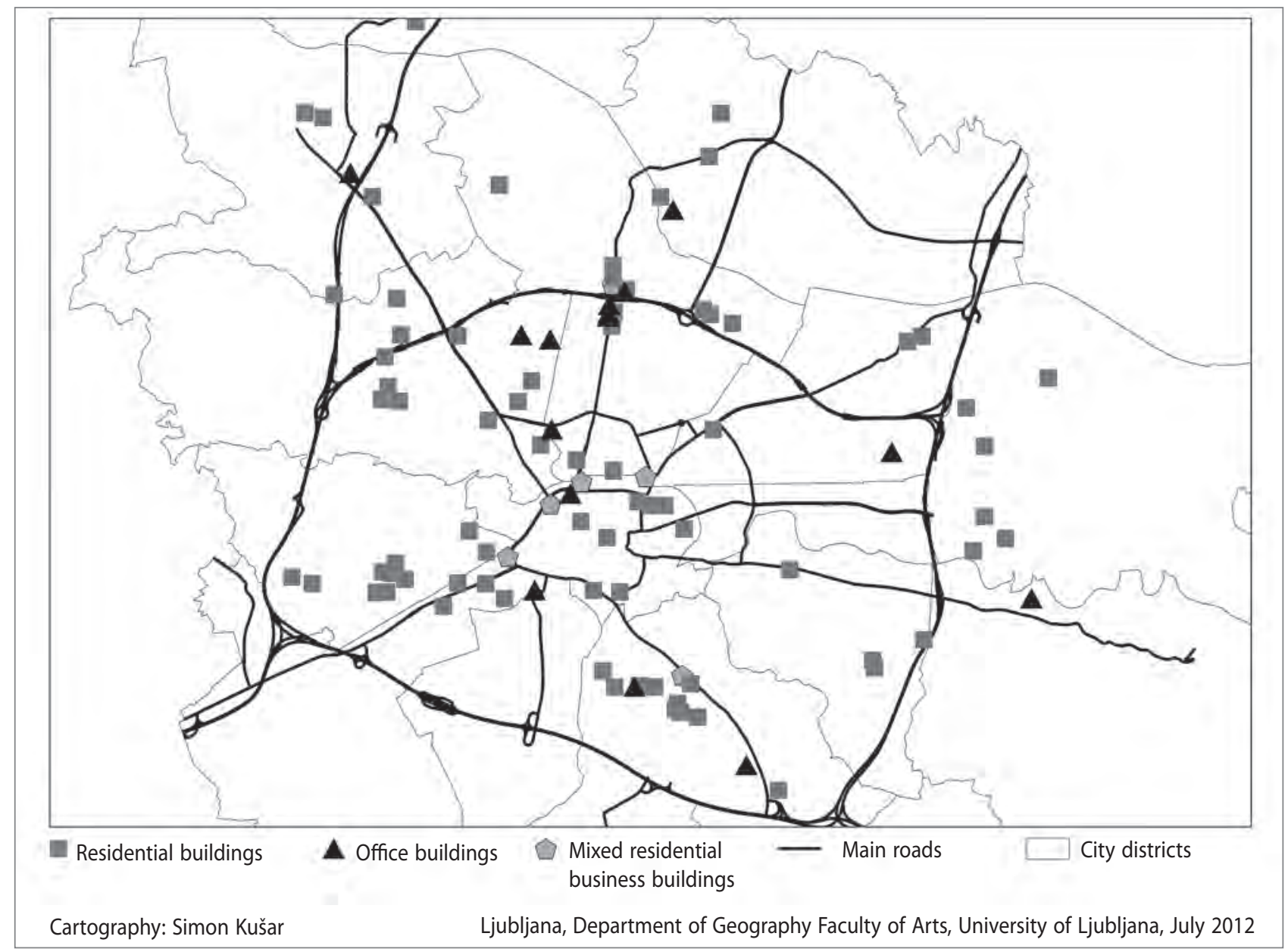

Figure 2: Location of dwellings surveyed in Ljubljana. 
one-fourth (26.3\%) of dwellings were over $500 \mathrm{~m}$ from main roads. A similar number of dwellings analysed were located closer to roads (23.7\%). Fifteen residential dwelling locations $(19.7 \%)$ were surveyed directly along the road.

In fifty units that were already built, there were 2,722 flats measuring approximately $190,000 \mathrm{~m}^{2}$. More than half of flats (55\%) were still unoccupied. Almost three-fourths (thirty-six units, or $72 \%$ ) were finished after the beginning of the economic crisis in Slovenia; that is, after 2008. These dwellings had a higher share of unoccupied area than those built before 2009.

Although only six projects were finished in 2010, the number of new (and still not fully occupied) flats reached 1,023. In this year two major investments were completed: Savski Breg in Črnuče and Celovški Dvori in Šiška. In the latter, more than 800 flats were built.

More than one-fourth (fourteen, or 28\%) of residential buildings surveyed were predominantly unoccupied. The majority of dwellings (46\%) were partly occupied, and in twelve dwellings (24.5\%) there were only a few flats still available. Nineteen residential housing were still under construction at the end of 2011, in which 344 flats were planned measuring $27,334 \mathrm{~m}^{2}$ altogether. They were located in the city districts of Rožnik (five residential houses under construction), Center (three), Bežigrad, Posavje, Rudnik and Šškka (two locations in each district) and Črnuče, Golovec and Šmarna Gora (one location in each district). Seven abandoned construction sites for residential dwellings were surveyed. Three were located in Polje, two in Bežigrad, and one each in Rožnik and Šiška.

Fifteen predominately office buildings in Ljubljana were surveyed. Eight buildings were finished after the beginning of the financial crisis, and six projects started being built but construction works stopped. There are more than $125,000 \mathrm{~m}^{2}$ of office area in the office buildings already built, but more than half $(58.4 \%)$ of them are still unoccupied.
Office buildings and groups of office buildings are mainly located along Dunajska Cesta at the northern ring road and in industrial zones that are being transformed into mixed business-commercial-production zones (Šiška, Moste). The calculated nearest neighbour index showed the trend of dispersion of office buildings that were included in the analysis $(I=$ $1.4072 ; p=0.00$ ). Because there must be at least thirty structures in the sample (Geoib, 2012), the calculated index did not reflect real conditions. Office buildings were very easily accessible from the main city roads and state roads. On average, they were $257 \mathrm{~m}$ from important roads. This is almost $100 \mathrm{~m}$ less than registered residential dwellings.

Six units had distinctively mixed functions. Two projects had already been completed, two of them were still under construction, and two of them were abandoned construction sites. The reasons for both abandoned construction sites were related not only to the economic crisis, but also to other (institutional) reasons. If all the projects had been built, then 1,051 new flats would be on the market and almost 200,000 $\mathrm{m}^{2}$ of office area. The majority of structures with mixed functions (four, or two-thirds) were located in the extended Ljubljana city centre and directly along the main transport corridors in Ljubljana.

\section{Discussion}

Investments in derived financial instruments that lost their value after financial shocks and difficulties in the real estate market in the United States caused serious liquidity problems in financial organisations. Because it was not clear how many toxic financial assets an individual bank had, trust between banks eroded. Trust is a key element and condition for successful development of the financial industry and undisturbed monetary flows. Banks stopped lending money among themselves because they could not guarantee the quality of their portfolio. Banks tried to limit their exposure to hazardous investments. They were subject to limitations on borrowing fresh financial means. Therefore, banks restricted their credit activities. However, that had a negative effect on economic development, which was based on a high degree of liquidity and on fresh credits. Lack of fresh financial resources decreased

Table 1: Basic characteristics of residential buildings

\begin{tabular}{lllll}
\hline Year of construction & Number of units surveyed & Number of flats & Area of flats (estimate) & $\begin{array}{l}\text { Average share of unoccupied } \\
\text { area (\%) }\end{array}$ \\
\hline 2006 & 3 & 57 & 5,090 & 24.3 \\
\hline 2007 & 6 & 156 & 21,189 & 36.3 \\
\hline 2008 & 5 & 266 & 35,853 & 35.5 \\
\hline 2009 & 19 & 1,018 & 79,022 & 63.0 \\
\hline 2010 & 6 & 1,023 & 32,930 & 57.8 \\
\hline 2011 & 11 & 202 & 16,029 & 68.5 \\
\hline Together & 50 & 2,722 & 190,113 & 55.7 \\
\hline
\end{tabular}


Table 2: Basic characteristics of office buildings, groups of office buildings and buildings with distinctively mixed functions

\begin{tabular}{lllll}
\hline Type & $\begin{array}{l}\text { Number of units } \\
\text { surveyed }\end{array}$ & Number of flats & Area of offices (estimate) & $\begin{array}{l}\text { Average share of unoccupied } \\
\text { area (\%) }\end{array}$ \\
\hline Predominately office buildings, built & 9 & 0 & 127,214 & 58.4 \\
\hline $\begin{array}{l}\text { Predominately office buildings, abandoned } \\
\text { construction sites }\end{array}$ & 6 & NA & NA & $/$ \\
\hline Distinctively mixed functions, built & 2 & 68 & 1,453 & 52.5 \\
\hline $\begin{array}{l}\text { Distinctively mixed functions, under con- } \\
\text { struction }\end{array}$ & 2 & 791 & 89,600 & $/$ \\
\hline $\begin{array}{l}\text { Distinctively mixed functions, abandoned } \\
\text { construction sites }\end{array}$ & 2 & 192 & NA & $/$ \\
\hline
\end{tabular}

Notes: NA = not available; / = not relevant

the demand for goods (Adair et al., 2009; Sendi, 2010), including real estate. The financial industry is characterised by a high degree of mutual connectedness, and therefore the global and local levels are strongly intertwined. Financial impediments were experienced not only by large investment banks that are global players in the financial industry, but also by smaller (regional and local) banks that greatly rely on global financial flows (Martin, 2011). This is why the financial crisis spread to almost all developed countries (Adair et al., 2009; Jagannathan et al., in press), including Slovenia. The lack of liquidity was transmitted into the real sector with some delay, but companies experienced difficulties in performing their activities and the value of gross domestic product decreased.

Slovenia experienced economic recession at the beginning of 2009, when a decrease in gross domestic product (GDP) was noted for two successive quarters of the year. The first quarter with a decrease in GDP was the fourth quarter of 2008. The earliest quarter of the year with a marked increased GDP was the second quarter of 2010. In other quarters of the year, the value of GDP stagnated (Statistical Office of the Republic of Slovenia, 2012). Slovenia had a relatively high increase in GDP before the financial and economic crisis. In 2007 it reached

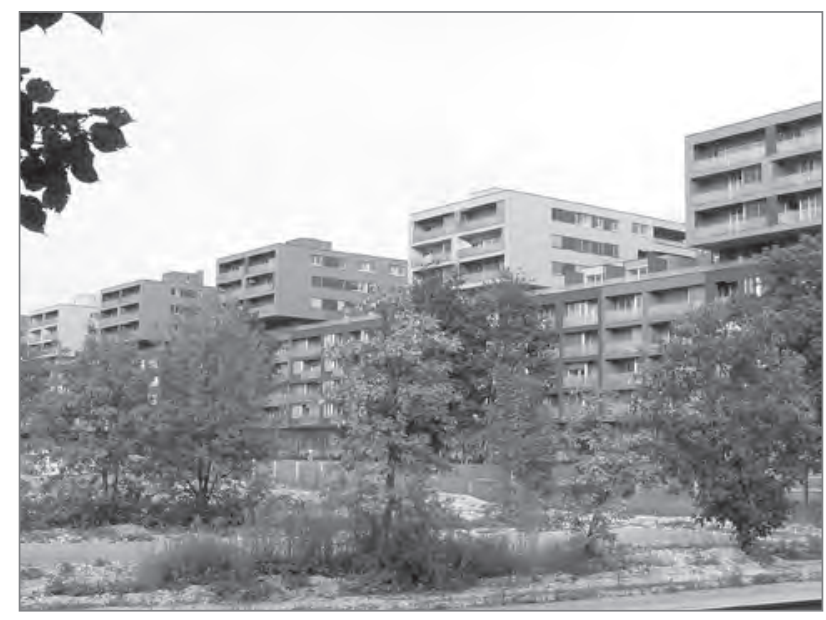

Figure 3: Celovški Dvori containing 800 flats is one of the largest predominantly residential complexes in Ljubljana (photo: Simon Kušar). almost 7\%. However, a few months later Slovenia was placed in the group of countries that experienced one of the most serious economic recessions in the European Union. Only Lithuania, Latvia, Estonia and Finland had a worse situation than Slovenia in 2009. Even the level of recovery was below the European Union average (Eurostat, 2012). The extension of the economic crisis in Slovenia is not exclusively a result of the global financial crunch and economic slowdown in countries that are important trade partners for Slovenia, but is also significantly due to specific national economic institutions: managers buying companies they controlled, the poorly developed financial market, mistrust of foreign direct investments and slowness in implementing reforms (Marn, 2010).

The Slovenian economy strongly depends on the international economic environment. Therefore, national banks were severely affected by the global credit crunch. Their credit activities for investing in dwellings and office buildings were depleted (Marn, 2010). New financial assets were scarce, and at the same time the demand for real estate decreased significantly. Sendi (2010) determined that a credit crunch in financing residential investment did not exist and that banks were still offering their clients loans to buy homes. However,

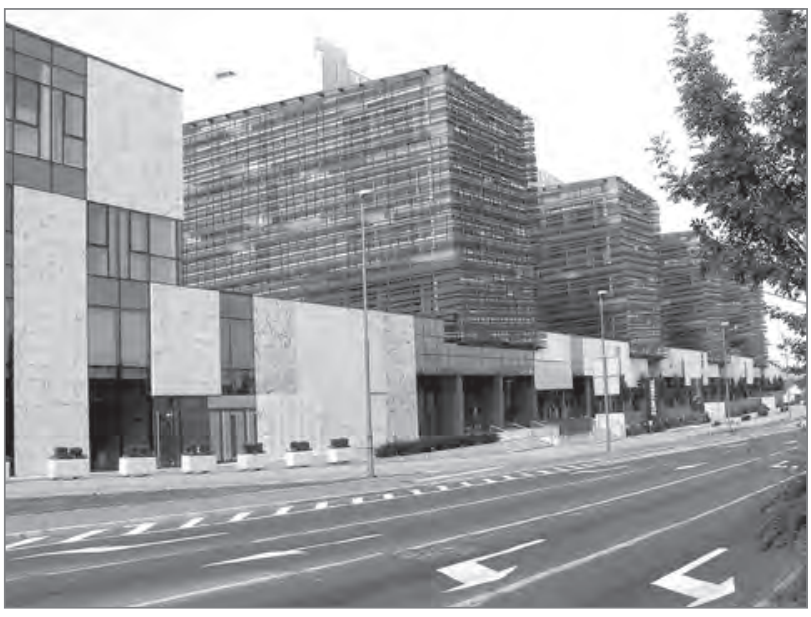

Figure 4: The Dunajski Kristali office building complex is located at the intersection of Dunajska Cesta and the northern ring road; only the building near Dunajska Cesta is occupied (photo: Simon Kušar). 
the credit crunch was strong in financing projects for small and large real estate and for construction companies. These investments were dependent on speculative indebtedness that stopped after the outbreak of the financial crisis. This was one of the main reasons for the insolvency and even bankruptcy of a number of real estate investment firms and construction companies that were not prepared for the financial crises; they were often highly indebted, with a lack of the free capital and financially exhausted by their managers trying to become their owners (Marn, 2010). It can be concluded that the financial crisis had a serious impact on construction activities in Slovenia (Sendi, 2010). After growth in 2006 and 2007, gross value added in construction decreased dramatically. It decreased by $15.5 \%$ in 2009 and by an additional $19.9 \%$ in 2010 (Statistical Office of the Republic of Slovenia, 2012). Part of this reduction might be a result of the completion of motorway construction in Slovenia, but evidently the dramatic decrease was result of the difficulties in real estate investments (Marn, 2010). The years before 2009 were marked by a boom in real estate investments. Until the last quarter of 2009 , every quarter of the year more than 1,000 building permits for new buildings were issued. The number of building permits decreased in the third quarter of 2008, whereas in the second quarter of that year it had a recorded maximum with 1,466 building permits for 1,166 residential buildings covering $393,079 \mathrm{~m}^{2}$ and 302 non-residential buildings with an area of $352,342 \mathrm{~m}^{2}$. In the first quarter of 2012, only 664 building permits were issued (Statistical Office of the Republic of Slovenia, 2012); therefore, the number of building permits issued compared to the second quarter of 2008 was more than halved. Ljubljana has a special status in Slovenia. It is not only the capital of Slovenia and the largest settlement in Slovenia by number of inhabitants (272,220 inhabitants in the 2011 census; Statistical Office of the Republic of Slovenia, 2012), but is also the most important and the largest economic centre. Out of 5,373 building permits for new dwellings issued in 2008 in Slovenia, 3\% (176) were issued to investors seeking to build or renovate buildings in the City Municipality of Ljubljana. In that year, the number of building permits issued in the City Municipality of Ljubljana was the largest. Only four other municipalities in Slovenia had more than 100 building permits issued in that year. Compared to the average number of building permits per municipality issued in 2008 (25.6), the City Municipality of Ljubljana received almost seven times more building permits (Statistical Office of the Republic of Slovenia, 2012). However, before the beginning of the economic crisis in Slovenia, the demand was higher than the supply. Therefore, the average price of dwellings in Ljubljana was markedly higher than the average price of dwellings throughout the rest of Slovenia, sometimes even comparable to prices in other capital cities in the European Union. Due to the financial and economic crisis, the real estate market almost collapsed in both
Slovenia and Ljubljana. The period before 2008 was marked by a high increase in the value of real estate in Ljubljana, which reached $10 \%$ annually. However, its value started to decrease in 2009 (Surveying and Mapping Authority of the Republic of Slovenia, 2010, 2011). Before the financial crisis, there was no sudden increase in prices of flats in Ljubljana, although they had gradually increased since the 1990s. Prices did not suddenly fall, as would have been typical for a housing bubble bursting. Sendi (2010) is convinced that a housing bubble was not present in Slovenia and Ljubljana. He concludes that the current stagnation in prices is the result of the financial and economic crisis. Some residential houses and office buildings were seized by leasing firms and banks because their investors were unable to service their debts. However, leasing firms and banks were not eager to sell the seized properties on the market below the prices determined before the economic crisis (Surveying and Mapping Authority of the Republic of Slovenia, 2010). Assets are not even being sold by construction and investment firms because they do not want to lower prices. On the other hand, demand is relatively weak. Buyers are not willing to pay such high prices when a significant decrease is expected. Because there is a high supply of dwellings, buyers have become more discriminating and are not willing to purchase properties that do not offer an optimal ratio of price, quality and accessibility (Marn, 2010). Other factors influence the low demand: unstable economic conditions and the decrease in purchasing power due to weak economic growth, a higher unemployment level, stagnation of real vales of salaries and insecure future conditions (Surveying and Mapping Authority of the Republic of Slovenia, 2010). Evidently, the financial crisis had an important impact on consumer behaviour (Sendi, 2010).

The result of mutually connected factors described above is numerous unoccupied or partly occupied newly built residential houses and office buildings, and abandoned construction sites. A field survey was conducted at the end of November 2011 in Ljubljana in which ninety-seven locations were found with individual dwellings built for the market or groups of single-family houses, semi-attached houses, blocks of flats and office buildings and their complexes. The majority of structures examined (fifty units) were built after the financial and economic crisis struck, but planned before the crisis. More than 1,500 empty flats were surveyed in these buildings; therefore, the informal estimates that there are thousands of unoccupied flats in Ljubljana proved to be true. These dwellings are a new element in the morphology of Ljubljana. They are mostly located in degraded areas of grey zones; therefore, they filled un-urbanised places in the city. The trend of the city becoming built more densely is actually following the guidelines of the national spatial development strategy (see Ministry of the Environment, Spatial Planning and Energy, 2004). This process 
has already been described by Rebernik $(2007,2010)$. He is convinced that developing cities on the inside is the result of a lack of the appropriate and accessible building plots around settlements. The spatial characteristics of the new buildings have less positive effects. Usually, the parcels are fully exploited, from one property line to the other. This decreases the quality of life for residents and their neighbours. New dwellings are sometimes located in morphologically homogenous areas but do not follow the original pattern. Flats are usually not well planned and therefore not suitable for young families with children. Construction on marshy areas and areas that may be affected by flooding, especially the southern part of Ljubljana, can also be problematic.

\section{Conclusion}

The causes and effects of the financial and economic crisis have attracted researchers from various fields. Their main research theme has been the (macro)economic causes and effects of the crisis. However, Martin (2011) has pointed out that geographical analyses are also needed. The geographical approach to studying the effects of the financial and economic crisis should include a micro-location analysis of the spatial effects of the crisis. Therefore, a study was conducted on unoccupied or partly occupied residential buildings and office buildings in Ljubljana that were built after 2005. The spatial elements studied are not exclusively the result of the financial and economic crisis in Slovenia, which is characterised by strong involvement into global circuits of production and consumption by the real and financial sector, but also a result of specific features of national economic institutions (managers buying companies they controlled, a poorly developed financial market, mistrust in foreign direct investments and slowness in implementing reforms). Therefore, the first thesis, that the real estate market difficulties in Ljubljana originated exclusively from the effects of the global financial and economic crisis, cannot be fully confirmed.

The location of unfinished or partly occupied newly built residential houses and business buildings in Ljubljana was defined during the field survey at the end of November 2011. The results of the field survey were analysed statistically and by using geographical information system software. Ninety-seven locations were surveyed for unoccupied or partly occupied residential houses and office buildings or groups of single-family houses, semi-attached houses, blocks of flats and office buildings together with abandoned or active construction sites. Therefore, the second thesis, which predicted more than fifty locations of dwellings and office buildings studied, can be confirmed. The majority of real estate $(78.2 \%)$ is predominately represented by several blocks of flats and groups of dwellings (seventy-six research units). All of the others are office buildings or buildings and complexes with distinctively mixed residential-business functions. There are more than 1,500 empty flats in the buildings and almost $75,000 \mathrm{~m}^{2}$ of office area. Although the structures are relatively scattered around Ljubljana, there were some clusters, especially along Dunajska Cesta close to the junction with the northern part of Ljubljana ring road, between Rožna Dolina and Vrhovci, and around Jurčkova Cesta in the southern part of the city. Some buildings are located in industrial zones that are being transformed into a mixed business-commercial-production zone (Šiška, Moste). Office buildings are located near national and major city roads, and residential houses are not as close to important transport corridors in Ljubljana. The third thesis cannot be fully confirmed because only office buildings experienced good accessibility. The relatively high dispersion of buildings follows the guidelines of the national spatial development strategy (see Ministry of the Environment, Spatial Planning and Energy, 2004), which is trying to direct development inside the morphological parts of settlements instead of green-field development. The urbanism of new buildings has less positive effects because they are often located in morphologically homogenous areas and do not follow the original spatial pattern of the neighbourhood. This decreases the quality of life for residents and their neighbours. The causes for the formation of the newly developed element studied in the morphological structure of Ljubljana are characterised by complexity and mutual connectedness. They include factors on the demand and supply side. The following factors were highlighted: the credit crunch, which seriously affected construction in Slovenia, causing insolvency and bankruptcy of construction firms and real estate investment companies, and difficulties in real estate investments caused by the insecure economic situation and a decrease in purchasing power. Potential investors are waiting for the prices of dwellings to fall.

In the future, the research should be extended further, especially to the suburban countryside around Ljubljana, where the past years have also seen an increase in the construction of residential buildings for the market. Furthermore, it would be interesting to conduct a comparative analysis between $\mathrm{Lju}$ bljana and other regional centres in Slovenia, and between Ljubljana and selected capital cities in central Europe.

\section{Simon Kušar}

University of Ljubljana, Faculty of Arts, Department of Geography, Ljubljana, Slovenia

E-mail: simon.kusar@ff.uni-lj.si

\section{Acknowledgement}

The author is grateful to the geography students that participated in the field research in the 2011/2012 academic year. 


\section{References}

Aalbers, M. (2009) Geographies of financial crisis. Area, 41(1), pp. 34-42. DOI: 10.1111/j.1475-4762.2008.00877.x

Adair, A., Berry, J., Haran, M., Lloyd, G. \& McGreal, S. (2009) The global financial crisis: Impact on property markets in the UK and Ireland. Belfast, University of Ulster.

Bieri, D. (2009) Financial stability, the Basel process and the new geography of regulation. Cambridge Journal of Regions, Economy and Society, 2(2), pp. 303-331.

Deep Sharma, G. \& Mahendru, M. (2011) Coping-up with the global economic recession: A study of USA, UK, India and China. Available at: http:// papers.ssrn.com (accessed 9 Jul. 2012).

Diewert, W. E., Nakamura, A. O. \& Nakamura, L. I. (2009) The housing bubble and a new approach to accounting for housing in a CPI. Journal of Housing Economics, 18(3), pp. 156-171. DOI: 10.1016/j.jhe.2009.07.008

Engleman, E. \& Faulconbridge, J. (2009) Financial geographies: The credit crisis as an opportunity to catch economic geography's next boat? Journal of Economic Geography, 9, pp. 587-596. DOl: 10.1093/jeg/ lbp037

European Commission (2009) Economic crisis in Europe: Causes, consequences and responses. 2009. European Economy, 7. Brussels, Directorate-General for Economic and Financial Affairs.

Eurostat (2012) GDP per capita in PPS. Available at: http://epp.eurostat. ec.europa.eu (accessed 28 Jun. 2012).

French, S., Leyshon, A. \& Thrift, N. (2009) A very geographical crisis: The making and breaking of the 2007-2008 financial crisis. Cambridge Journal of Regions, Economy, and Society, 2(2), pp. 287-302.

Geoib (2012): Nearest neighbour index. Available at: http://www.geoib. com (accessed 16 Jul. 2012).

Greenspan, A. \& Kennedy, J. (2008) Sources and uses of equity extracted from homes. Oxford Review of Economic Policy, 24(1), pp. 120-144. DOI: 10.1093/oxrep/grn003

Hammond, R. \& McCullagh, P. (1974) Quantitative techniques in geography: An introduction. Oxford, Clarendon Press.

Hodgson, G. (2009) The great crash of 2008 and the reform of economics. Cambridge Journal of Economics, 33(6), pp. 1205-1221. DOI: $10.1093 /$ cje/bep050

Holloway, A. (2008) Safe as houses? Canadian Business, 81(7), pp. 58-71.

International Monetary Fund (2008) World economic outlook. October 2008. Financial stress, downturns, and recoveries. Washington, DC.

Jagannathan, R., Kapoor, M. \& Schaumburg, E. (in press) Causes of the great recession of 2007-2009: The financial crisis was the symptom not the disease! Journal of Financial Intermediation. DOI: 10.1016/ j.ji.2012.06.002

Kitchin, R., Gleeson, J., Keaveney, K. \& O'Callaghan, C. (2010) A haunted landscape: Housing and ghost estates in post-Celtic tiger Ireland. Maynooth, NUI Maynooth, National Institute for Regional and Spatial Analysis.

Lawson, T. (2009) The current economic crisis: Its nature and the course of academic economics. Cambridge Journal of Economics, 33(4), pp. 759-778. DOI: 10.1093/cje/bep035

Marn, U. (2010) Gradbinci na udaru. Velika gradbena podjetja so z visokimi cenami branila profite in $s$ tem lastnike, to pa je povzročilo nelikvidnost, ki gre na račun delavcev, dobaviteljev, podizvajalcev in tudi bank. Mladina, 11, 18 Mar. 2010, pp. 37-40.
Martin, R. (2011) The local geographies of the financial crisis: From the housing bubble to economic recession and beyond. Journal of Econo mic Geography, 11(4), pp. 587-618. DOI: 10.1093/oxrep/grn003

Ministry of the Environment, Spatial Planning and Energy (2004) Spatial development strategy of Slovenia. Ljubljana.

O'Brien, R. \& Keith, A. (2009) The geography of finance: After the storm. Cambridge Journal of Regions, Economy and Society, 2(2), pp. 245-265.

Parkinson, M., Ball, M., Blake, N. \& Key, T. (2009) The credit crunch and regeneration: Impact and implications. London, Department for Communities and Local Government.

Priemus, H. (2010) The credit crunch: Impacts on the housing market and policy responses in the Netherlands. Journal of Housing and the Built Environment, 25(1), pp. 95-116. DOI: 10.1007/s10901-009-9175-8

Rebernik, D. (2007) Trajnostni prostorski razvoj in novejši procesi v prostorskem razvoju Ljubljane. Dela, 27, pp. 17-38.

Rebernik, D. (2010) Teorija in praksa prostorskega načrtovanja: prostorski razvoj mest in širših mestnih območij v Sloveniji. Dela, 33, pp. 111-127.

Sendi, R. (2010) Mehurček ali kreditni krč: kaj se dogaja na slovenskem stanovanjskem trgu? [Housing bubble burst or credit crunch effect? Slovenia's housing market]. Urbani izziv, 21(2), pp. 27-36 [96-105]. DOI: 10.5379/urbani-izziv-en-2010-21-02-003

Statistical Office of the Republic of Slovenia (2012) SI-STAT podatkovni portal. Available at: http://www.stat.si (accessed 28 Jun. 2012).

Stiglitz, J. E. (2009) The financial crisis of 2007-2008 and its macro-economic consequences. Available at: http://unpan1.un.org (accessed 3 Nov. 2012).

Surveying and Mapping Authority of the Republic of Slovenia (2010) Poročilo o slovenskem nepremičninskem trgu za leto 2009. Ljubljana.

Surveying and Mapping Authority of the Republic of Slovenia (2011) Poročilo o slovenskem nepremičninskem trgu za leto 2010. Ljubljana.

Yao, S., Luo, D. \& Morgan, S. (2010) Impact of the US credit crunch and housing market crisis on China. Journal of Contemporary China, 19(64), pp. 401-417. DOI: 10.1080/106705609034443355

Wojcik, D. (2009) Geography stupid! A note on the credit crunch. Environment and Planning, $A$, 41(2), pp. 258-260. DOI: 10.1068/a41160 